\title{
Role of Teachers Class as A Motivator and Guidance Students in Education of Discipline Character Through Movement of School Literation According to Nawacita in Elementary School of Gabus 01 Pati 2017/2018 Academic Year
}

\author{
Dwi Anggraeni Siwi ; Nurratri Kurnia Sari \\ Univet Bantara, Sukoharjo, Indonesia \\ Email: dwianggraenisiwi@univetbantara.ac.id
}

http://dx.doi.org/10.18415/ijmmu.v6i1.459

\begin{abstract}
The purpose of this study was to describe the role of class teachers as motivators and mentors in disciplined character education and to know the factors that hinder the formation of the character of students of Elementary School of Gabus 01 Pati 2017/2018 Academic Year. This research is a descriptive qualitative research conducted at the Elementary School Of Gabus 01 Pati. The subjects of this study were students from grade 1 to 3 of Elementary School Of Gabus 01 Pati as many as 6 students and 3 class teachers, namely first grade to third grade teachers. The instruments used were interviewed, observation, and documentation. The data analysis technique used is a model according to Miles \& Huberman using a descriptive qualitative analysis. The results of this study are the role of class teachers as motivators are very important in the formation of the character of student discipline, the teacher provides motivation or encouragement to students in the form of rewards/ praise, open to the work of students, provide forms of competition, and give punishment to students who are not disciplined orderly school. The role of the teacher as a mentor, the guidance given to students is tutoring, social and personal guidance. Providing guidance to students is not only during lessons, but guidance is also given during literacy activities. While the inhibiting factors in the formation of the character of student discipline are internal and external factors. Internal factors that inhibit the formation of the students' character, discipline are innate, lack of awareness and interest of students. Whereas external factors that hinder the formation of student discipline, character are environmental factors outside of school such as family, play environment, and community.
\end{abstract}

Keywords: Role of Class Teacher; Character; Discipline of Student Education; Literacy Activities

\section{Introduction}

Education is a conscious and planned effort in the process of coaching and learning for individuals to grow, to develop into an independent, responsible, creative, knowledgeable, healthy and noble (character) person (Law No. 20 of 2003). Regarding character education, the government strengthened character education by forming a Literacy Movement. The understanding of GLS in the guidance of the School Literacy Movement (2016: 1) is an overall effort to make schools a learning organization whose citizens are literate throughout their lives through public involvement. The GLS is 
developed based on nine priority agendas (Nawacita) which are related to the tasks and functions of the Ministry of Education and Culture, specifically Nawacita number 5, 6, 8, and 9. Nawacita points which are intended are 5) improving the quality of human life and Indonesian society; 6) increasing people's productivity and competitiveness in international markets so that the Indonesian people can advance and rise with other Asian nations; 8) revolutionizing the character of the nation; 9) strengthens diversity and strengthen Indonesia's social restoration. Nawacita's four points are closely related to the literacy component as the capital for the formation of quality, productive and competitive human resources, as well as nationalist human resources.

According to Usman (2013: 7), the teacher's job as a profession includes educating, teaching, and training. Educating means continuing and developing life values. Teaching means continuing and developing science and technology. While training means developing skills in students. Teachers are also the dominant factor in education. Ordinary teachers just teach and provide material in accordance with the curriculum, whereas being a teacher is not just teaching or conveying subject matter but also must understand the psychology and needs of students. Students not only need enough learning with good academic value. But students also need guidance and motivation from a teacher. Motivating students is also very important to support success in student learning. Students need creative, inspiring and innovative educators who can guide students to become students who are not only intelligent but also of good character.

In essence, good character has existed since human being was born, but to maintain the character needs to be carried out continuously. Therefore, character formation starts from the family, family, school and community. School is a strategic place for character education because children from all walks of life will receive an education at school. Most of the time a child is spent in school, so that automatically what children get at school will affect the formation of their character. In the classroom teacher, school also influences character formation, namely by the guidance and motivation given by the class teacher to students.

From the results of interviews with researchers with the principal and teacher of Elementary School of Gabus 01 Pati, said that now there is a lack of respect for students for their teachers, especially young teachers whom they consider to be friends so they do not need to be respected. In addition, the lack of discipline of students in school is like going to school late and lacking in time. There are several possibilities that can cause students to lack good character. This makes the researchers want to explore how the class teacher in guiding and forming good character in Elementary School of Gabus 01 Pati students.

Based on this background, researchers want to do research with the title " The Role of Teachers Class As A Motivator And Guidance Students in Education of Discipline Character Through Movement of School Literation According to Nawacita in Elementary School of Gabus 01 Pati 2017/2018 Academic Year.

\section{Methodology}

This research method uses a descriptive qualitative research type that is by exploring or seeing the social situation of the research object in depth. In this study trying to be able to answer how the role of the teacher as a motivator and mentor of students in disciplined character education through the school literacy movement at Elementary School of Gabus 01 Pati.

This research was conducted at Elementary School of Gabus 01 Pati, Gabus Subdistrict, Pati District. This research was carried out in March to June 2018. 
The research subject is the subject intended by the researcher to be studied. The object of research is the object that becomes the focus of research. In this study, the subject of the study was the first grade teacher up to third grade Elementary School of Gabus 01 Pati and the first grade students up to third grade Elementary School of Gabus 01 Pati. While the object of research is how the role of class teachers in guiding and motivating students so that students have good discipline character through the school literacy movement.

The instruments used in this study include: Documentation Sheets, Teacher Interview Guidelines and student interview guidelines, as well as Observation guidelines.

In this study, researchers used data collection techniques as follows: 1) Interview (this interview was used to find data about the role of class teachers as motivators and mentors in disciplined character education through school literacy movements with resource persons, namely classroom teachers and students; 2) Observation: The activity in this observation is to observe the role of the teacher as a motivator and guide for students with discipline, character education, as well as observing how school literacy activities in forming good discipline character; 3) Documentation: This documentation technique is to retrieve student data from library visitors, student interviews, teacher interviews, and literacy activities.

The data analysis used in this research is an interactive model of qualitative data analysis techniques. According to Miles \&Huberman (1984) in Nugrahani (2015: 152) this interactive model analysis has three components, namely: 1) data reduction; 2) data presentation; 3) conclusion drawing.

\section{Results}

The following are the results of research that has been carried out at Elementary School of Gabus 01 Pati as follows:

\section{The Role of Teachers as Motivators}

The role of the class teacher as a motivator in character education, especially the character of discipline is very important. Competition is important for students, as said by Mrs. Hani Widiastuti,S.Pd as a class 2B teacher as follows: "Competition is important, with the competition later the children will be motivated by themselves, the form of competition is usually the group, later the group points or values can get the most. "(CL/W/G/001).

In addition to motivating students, the teacher also gives punishment if there are students who are not polite or not disciplined towards the school rules as said by Mr. Mat Jalil,S.Pd as follows: "Yes, it sanctioned. For example, there is a student guardian there, there is a guest, he is not polite, the guest is sitting, but he paces back and forth in front of him I immediately call him. We reprimand, reminded, Let him know, to be able to distinguish good and bad deeds. (CL/W/G/003).

The strategy of each teacher in handling students who are not different in the discipline, such as 2B class teacher Mrs. Hani Widiastuti,S.Pd gives the following answers: "Given sanctions according to the rules, not to be physical. Usually told to do something to be able to improve discipline. Usually taken to counseling, guidance. If there is no elementary school counselor in elementary school, the one who handles religion is usually a teacher. "(CL/W/G/001). 
Besides giving praise to students is very important. When given praise, students will feel happy and motivated as stated by Mrs.Sudarsih,S.Pd.SD as follows: "It is important, because the child will be happy if the results of his hard work are praised. For example, it's very clever, it's good, given a thumbs up. "(CL/W/G/01). The role of the teacher as a motivator cannot be separated from the personality of the teacher himself. Before giving motivation to students, a teacher must be able to be an example for his students. This was explained by the head of Elementary School of Gabus 01 Pati Mr. Haji Supeno,S.Pd as follows: "The figure of the teacher is very influential, the figure of a teacher who can be a good role model for students is the teacher who has time discipline, discipline in carrying out duties, good character including honesty, and look polite. " (CL/W/KS/001).

A teacher must be open to student learning outcomes. When students know their grades are good, students will be happy and if students get bad grades, they will be motivated so that their grades are better. Like Keysa, grade 3A students who responded as follows: "What do you do if you get a bad score?" "Yes, study again." "How do you feel if there are other friends who get better scores than you?" it can also be of good value. "" Will you study harder so that your score is higher? "" Yes. "(CL/W/S/006).

Motivation is given not only during learning or about learning, while other activities such as teacher, literacy activities also provide motivation for students. Before reading activities, the teacher motivates students to complete the reading books they choose within a certain period of time depending on the thickness of the book and do not forget to always fill literacy journals (CL/OBS/002).

\section{The Role of Teachers as Counselors}

As a mentor, class teachers also play a very important role in the formation of students' disciplinary character. Not only in teaching and learning activities, but also during literacy activities as stated by Mrs.Sudarsih, S.Pd.SD as follows: "Assisted, you can read it. Sometimes the teacher reads the students listening. But more students read to train them to read more. If anyone doesn't understand, the parts that he doesn't understand are explained. "(CL/W/G/002).

Like grade 3A teacher Mr. Mat Jalil,S.Pd also gave answers regarding the importance of the teacher's role as a mentor as follows: "It's very important, because students still have to be guided both in learning and acting... Yes guided by Ms., if students don't understand it explained. If there is a wrong action, we admonish us, remind us. "(CL/W/G/003).

Especially for class 1 which is an early class, guidance is very important. A teacher plays an important role in the formation of student character, the teacher also trains students to be disciplined so that later students are used to being disciplined as answered by Sudarsih S.Pd.SD as follows: "Yes, trained by Ms., because class 1 was the beginning so if successful later it's easy to be guided to the next class. Because training children to be the most disciplined when they are still in the lower classes, let alone class 1, basically, start. "(CL/W/G/002). This type of guidance is not just one, for example in class 1C teacher tutoring Mrs.Sudarsih,S.Pd.SD said as follows: "In the lesson, I am guided in understanding the material or working on questions that have not been understood until he understands." (CL/W/G/002). In addition to providing tutoring, teachers also provide social and personal guidance as explained by Mrs.Sudarsih,S.Pd.SD as follows: "How to overcome if there are students who are having difficulty interacting/socialize? "" Approached first, then we find out first why the reasons were just resolved. "" How to overcome if there are students who have personal problems? "" Just like you did, approached and guided. "(CL/W/G/002).

The form of providing guidance to students is divided into two, namely individually and concurrently, adjusted the ability of students as told by Mr. Haji Supeno,S.Pd as the principal of 
Elementary School of Gabus 01 Pati as follows: "Guidance is usually done individually and together, for those who individuals must still be adapted to their abilities. Because the children's abilities and characteristics vary, children are unique, so they have to understand each of their students. "(CL/W/KS/001).

Providing guidance to students not only during lessons, but also during literacy activities, when students have difficulty in choosing books or understanding the content of teacher reading also helps guide students. Like grade 2B student Faiz Rizky gave the following answers: "Have you ever had trouble understanding the contents of the book reading?" "Yes, I have". "(CL/W/S/O02). During literacy activities, the teacher tries to create a conducive atmosphere, the teacher also guides students who do not understand or have difficulty understanding the contents of the reading. The teacher also helps students who have difficulty choosing books (CL/OBS/002).

\section{Inhibiting Factors in the Formation of Student Discipline Characteristics}

In forming the character of student discipline in school, most class teachers have almost succeeded, but there are still inhibiting factors in the formation of the character of student discipline, especially environmental factors outside of school such as family, play environment, and community. This is, as stated by Mr. Mat Jalil,S.Pd as follows: "Very influential. For example, here is the method of manners, courtesy, but in the society he associates with his friends, many are influenced again by the character of his attitudes. Manners, how manners after leaving the class, how manners after leaving school were dispersed again. If you are afraid of the teacher here, he acts polite but after going back to the community again. "(CL/W/G/003). In line with Mr. Mat Jalil,S.Pd, Mrs.Sudarsih,S.Pd. SD also gave the following explanation: "Usually from home/parents, now we are a little difficult because if in school it has been taught but until the parents' house do not support it's hard. "

In addition for environmental factors, there are also internal factors that come from within, namely the carrier factor. Mrs. Hani Widiastuti,S.Pd gave the following explanation: "How come the lady is also the influence of parents too. Moreover, the time is lacking because the child is longer at home than at school. "(CL/W/G/001). Another factor that hinders the formation of students' discipline, character is interesting. The teacher's strategy in dealing with students' low interest in reading as stated by Mrs. Hani Widiastuti is as follows: "What is the mother's teacher's strategy in handling students who do not or are not interested in reading during literacy activities?" "Given a book that might interest him. Suppose the picture. Because literacy activities are very important, because children are trained to understand a story. Later, after reading the story, it was written again as a journal. But for now we want to accredit it so the book is still being processed. "(CL/W/G/001).

Environmental factors are very influential in the process of forming students' disciplinary character. As told by Mr. Haji Supeno,S.Pd as the Principal of Elementary School of Gabus 01 Pati as follows: "Advised, if the home environment for example at home is not accustomed to discipline it is already difficult. In school, children are used to teaching to discipline, but when they arrive at the house, it is the responsibility of parents. Well, if you feel the attitude of the child is out of bounds, we call the master. "(CL/W/KS/001).

The internal factors that influence the formation of the character of student discipline are student awareness. When learning difficulties or having problems, students prefer to ask for help from their friends rather than the teacher, as said by FaizRizky, grade 2B students as follows: "Can you complete the assignment given by the teacher's mother alone?" sometimes. "" Have you ever asked for someone else's help when doing assignments? If ever to whom? "" Yes, with friends. "(CL/W/S/002). When observing in the library there were no library officers in charge of maintaining the library at Elementary School of

Role of Teachers Class as A Motivator and Guidance Students in Education of Discipline Character Through Movement of School Literation

According to Nawacita in Elementary School of Gabus 01 Pati 2017/2018 Academic Year 
Gabus 01 Pati. (CL/OBS/001). This certainly affects literacy activities in the library, because an officer is very necessary in managing and maintaining the library.

Based on the results of interviews with classroom teachers, students and principals and from the observations showed that the role of class teachers as motivators and mentors in forming the character of discipline through the school literacy movement is good, but there are still some obstacles, especially obstacles from environmental factors outside the school and incomplete literacy journals that make class teachers guide and provide motivation to students in the formation of discipline character to be less than optimal. In addition, there is no library staff who helps manage and maintain the library. In supporting literacy activities, the school attaches posters that support literacy activities. Posters or writings are posted on the walls of the class, canteen, UKS, and others. The posters or writings are very supportive of literacy activities because students often see and read them and encourage students to do as written on the posters.

\section{Discussion}

\section{The Role of Teachers as Motivators}

The results showed that the role of class teachers as motivators is very important in character education through school literacy activities. As a motivator, the teacher plays a role in giving motivation to students. The form of motivation that can be given is by giving reasonable praise to students, always open to student learning outcomes and giving punishment to students who are not disciplined towards school discipline. In addition the teacher can also provide a form of competition for students. This can encourage students to be more disciplined and disciplined towards school discipline.

The teacher's strategy in dealing with students who are not polite or undisciplined towards school rules is different, the most important is that the punishment given is not physical or severe, the form of punishment must be positive so that students are motivated and motivated not to repeat the same mistakes and be more disciplined. Praise is also very important to motivate students. A teacher must be open to student learning outcomes. When students know their grades are good, students will be happy and if students get bad grades, they will be motivated so that their grades are better.

Motivation is given not only during learning or about learning, while other activities such as teacher, literacy activities also provide motivation for students. Before reading activities, the teacher motivates students to complete the reading books they choose within a certain period of time depending on the thickness of the book and do not forget to always fill in literacy journals. Literacy journals are very important in literacy activities, because literacy journals can foster interest in reading and honing students' abilities. With literacy journals, students can write detailed books and write down important figures and points from reading books.

\section{The Role of Teachers as Counselors}

As a mentor, the teacher plays a role in guiding students. Not only in teaching and learning activities, but also provide guidance such as social and personal guidance. A teacher plays an important role in the formation of student character, the teacher also trains students to be disciplined so that later students are used to being disciplined. The form of giving guidance to students is divided into two, namely individually and together, for individuals to be adjusted to students' abilities because the abilities and characteristics of each child are different. Social and personal guidance are the teacher guiding students who have personal problems such as leaking or difficulty in socializing, difficulty in issuing opinions, embarrassed to talk, and so on. Providing guidance to students is not only during lessons, but 
guidance is also given during literacy activities, teachers participate in literacy activities by creating a conducive atmosphere during literacy activities, teachers also guide students who are struggling with understanding the contents of the reading.

\section{Inhibiting Factors in the Formation of Student Discipline Characteristics}

In the formation of the character of student discipline in school most class teachers have almost succeeded, but there are still inhibiting factors in the formation of the character of student discipline, especially environmental factors outside of school such as family, play environment, and society. In addition to environmental factors, there are also internal factors that hinder the formation of students' character of disciplines such as low interest, character, and student awareness. When it is difficult to do the task or when there are problems, students prefer to ask for help from their friends rather than the teacher, of course it can hamper the process of forming a disciplined character. Another inhibiting factor is the lack of complete literacy journals that make a classroom teacher's guide and motivate students to form discipline characters to be less than optimal. In addition, there is no library staff who helps manage and maintain the library.

In forming the character of student discipline, literacy activities play an important role. But not apart from the role of a teacher in providing motivation and guidance to students. The teacher's strategy in instilling the character of discipline in students starts first from the teacher itself because a teacher must be able to be a good role model for his students. In instilling the character of discipline in students is done through habituation and training so that children will be accustomed to discipline and have good discipline character.

\section{Conclusion}

Based on the results of research and discussion, the conclusions of this study include the following:

1. The role of the teacher as a motivator is very important in student discipline character education. As a motivator, the teacher gives motivation or encouragement to students in the form of praise, is open to the work of students, provides a form of competition, and provides punishment for students who are not disciplined towards school rules. Motivation is not only given during lessons, but also during literacy activities, namely by encouraging students to complete the reading books they choose within a certain period of time depending on the thickness of the book and not forgetting to always fill literacy journals.

2. The role of the teacher as a mentor is very important in forming the character of student discipline. Guidance given to students is tutoring, social and personal guidance. Providing guidance to students is not only during lessons, but guidance is also given during literacy activities.

3. Inhibiting factors in the formation of the character of student discipline are internal and external factors. Internal factors that inhibit the formation of the students' character, discipline are innate, lack of awareness and interest of students. Whereas external factors that hinder the formation of student discipline, character are environmental factors outside of school such as family, play environment, and community. 


\section{References}

Djamarah, Syaiful. (2010). Guru dan Anak Didik dalam Interaksi Edukatif. Jakarta: Pt Rineka Cipta.

Gultom, Syawal dkk. (2017). Bahan Ajar PLPG Kebijakan Pengembangan Profesi. Universitas Negeri Medan. Panitia Sertifikasi Guru Rayon 102 Medan.

Isjoni. (2009). Guru Sebagai Motivator Perubahan. Yogyakarta: Pustaka Pelajar.

Kalida, Muhsin, dan Mursyid. (2014). Gerakan Literasi Mencerdaskan Negeri. Yogyakarta: Aswaja Pressindo.

Kemendikbud. (2016). Panduan Gerakan Literasi Sekolah di Sekolah Dasar. Jakarta: Kementerian Pendidikan dan Kebudayaan.

Lickona, Thomas. (2014). Pendidikan Karakter. Bandung: Nusa Media.

Nugrahani, Farida. (2015). Metode Penelitian Kualitatif dalam Bidang Pendidikan Bahasa. Surakarta: Cakrabooks solo.

Nugrahani, Farida. (2011). Penanaman Nilai-Nilai Kearifan Lokal melalui Pembelajaran "UnggahUngguhing Basa" dalam Upaya Pembentukan Karakter Generasi Muda, Malang: Universitas Muhammadiyah Malang.

http://digilibfkip.univetbantara.ac.id/materi/Prosiding\%20Penanaman\%20Nilai-nilai.pdf. (accessed on 02 June 2018).

Nugrahani, Farida. (2016). Pentingnya Peran Keluarga, Masyarakat, dan Sekolah Secara Terpadu dalam Pembinaan Bahasa Jawa dan Pendidikan Karakter di Era Global, Lampung 24-26 September.

http://digilibfkip.univetbantara.ac.id/materi/LAMPUNG.pdf (accessed on 02 June 2018).

Samani, Muchlas, dan Hariyanto. (2011). Konsep dan Model Pendidikan Karatkter. Bandung: PT Remaja Rosdakarya Offset.

Suyadi. (2015). Strategi Pembelajaran Pendidikan Karakter. Bandung: PT Remaja Rosdakarya Offset.

\section{Copyrights}

Copyright for this article is retained by the author(s), with first publication rights granted to the journal.

This is an open-access article distributed under the terms and conditions of the Creative Commons Attribution license (http://creativecommons.org/licenses/by/4.0/). 